\title{
Grassland birds associated with agricultural riparian prac- tices in southwestern Wisconsin
}

\author{
ROSALIND B. RENFREW AND CHRISTINE A. RIBIC
}

Authors are graduate student and unit leader/associate professor, USGS BRD Wisconsin Cooperative Wildlife Research Unit, Department of Wildlife Ecology, 1630 Linden Drive, University of Wisconsin, Madison, Wisc. 53706.

\section{Abstract}

Rotational grazing has been proposed as a Best Management Practice (BMP) for minimizing runoff in Wisconsin agricultural riparian areas. The influence of this land management practice on grassland birds has not been evaluated in relation to more traditional agricultural land management systems in Midwestern riparian areas. This study compared the grassland bird community in riparian areas in Wisconsin that were rotationally grazed to 2 common land use practices along streams in Wisconsin: continuously grazed pastures and rowcrop fields with 10-m-wide ungrazed buffer strips located along the stream. We calculated total number of birds, the Berger-Parker Index of Dominance, and number of birds ha $^{-1}$ for each site. Vegetation variables used were height-density, litter depth, and percent bare ground. Bird species richness, species dominance, and density did not differ among land use types. In contrast, grassland bird species of management concern [Savannah Sparrow (Passerculus sandwichensis Gmelin), Eastern Meadowlark (Sturnella magna L.), and Bobolink (Dolichonyx oryzivorus $\mathbf{L}$.)] were found on continuous and rotational pastures but very rarely or never occurred on buffer strips. Contrary to previous research, however, rotationally grazed pastures did not support more of these species than continuously grazed pastures. Bird density was related to vegetation structure, with higher densities found on sites with deeper litter. Within the pasture land use types, there were no consistent differences between species richness and density near the stream $(<10 \mathrm{~m})$ and away $(>10 \mathrm{~m})$.

Key Words: pastures, rotational grazing, species richness, density, dominance, buffer strips

Grassland birds have been declining faster and more consistently than any other avian guild in North America in the last 30 years (Knopf 1995). Pastures in Wisconsin support several breeding grassland bird species of management concern (Sample and Mossman 1997, Wisc. Natural Heritage Program 1999), includ-

Research was funded by a University of Wisconsin-Madison Hatch Grant, USFWS Partnerships for Wildlife, the Wisconsin Department of Natural Resources, and the USGS BRD Wisconsin Cooperative Wildlife Research Unit. Authors wish to thank all the farmers, whom are too numerous to name, for so willingly and generously allowing access to their land. We thank Susan Chin, Brick Fevold, and Matt Nafranowicz for their dedicated field work. We thank Laura Paine and Pamela Pietz for reviewing a draft of this manuscript. We would also like to acknowledge our collaborators in the Agricultural Ecosystems Research Project who made this research possible: Laura Paine, Dan Undersander, Jerry Bartelt, Dave Sample, and John Lyons.

Manuscript accepted 5 Nov. 00.

\section{Resumen}

El apacentamiento rotacional ha sido propuesto como una Buena Practica de Manejo (BPM) para minimizar el escurrimiento en las áreas ribereñas agrícolas de Wisconsin. La influencia de esta practica de manejo de tierras en las aves del pastizal no ha sido evaluada en relación a los sistemas mas tradicionales de manejode las áreas ribereñas del medio oeste. Este estudio comparó la comunidad de aves de pastizal en áreas ribereñas apacentadas rotacionalmente contra dos prácticas comunes utilizadas a lo largo de corrientes de agua en Wisconsin: potreros apacentados continuamente y campos sembrados con cultivos en surcos y con franjas de amortiguamiento sin apacentar de $10 \mathrm{~m}$ de ancho localizadas a lo largo de las corrientes. Calculamos el número de aves, el indice de dominancia ed Berger-Parker y el número de aves ha $^{-1}$ para cada sitio. Las variables de vegetación utilizadas fueron: altura-densidad, profundidad del mantillo y porcentaje de suelo desnudo. La riqueza de especies de aves, dominancia de especies y densidad no difirieron entre los tipos de uso de la tierra. En contraste, las especies de aves del pastizal de interés de manejo, [Savannah Sparrow (Passerculus sandwichensis Gmelin), Eastern Meadowlark (Sturnella magna L. and Bobolink (Dolichonyx oryzivorus L.)] se encontraron en los potreros apacentados rotacional y continuamente, pero muy raramente o nunca se encontraron en las franjas de amortiguamiento. Sin embargo, Contrario a la investigación previa, los potreros apacentados rotacionalmente no sostienen mas de estas especies que lo que sostienen los potreros apacentados continuamente. La densidad de aves se relaciono a la estructura de la vegetación, con mayores densidades encontradas en sitios con mantillo profundo. Dentro de los tipos de uso de los potreros no hubo diferencias consistentes entre la riqueza de especies y la densidad cerca de las corrientes $(<10 \mathrm{~m})$ o lejos de ella $(>10 \mathrm{~m})$.

ing Grasshopper Sparrow (Ammodramus savannarum Gmelin), Eastern Meadowlark (Sturnella magna L.), Western Meadowlark (Sturnella neglecta Audubon), Bobolink (Dolichonyx oryzivorus L.), Sedge Wren (Cistothorus platensis Latham), Upland Sandpiper (Bartramia longicauda Bechstein), and Savannah Sparrow (Passerculus sandwichensis Gmelin). Management of grasslands for the benefit of these species is a priority in Wisconsin and elsewhere (e.g., Jones and Vickery 1996, Swanson 1996, Herkert 1991, Herkert et al. 1996).

The purpose of this study was to compare the avian communities of management intensive rotationally grazed (MIRG) riparian areas to those in 2 common riparian land management options in southwestern Wisconsin: continuously grazed (i.e., conventional) 


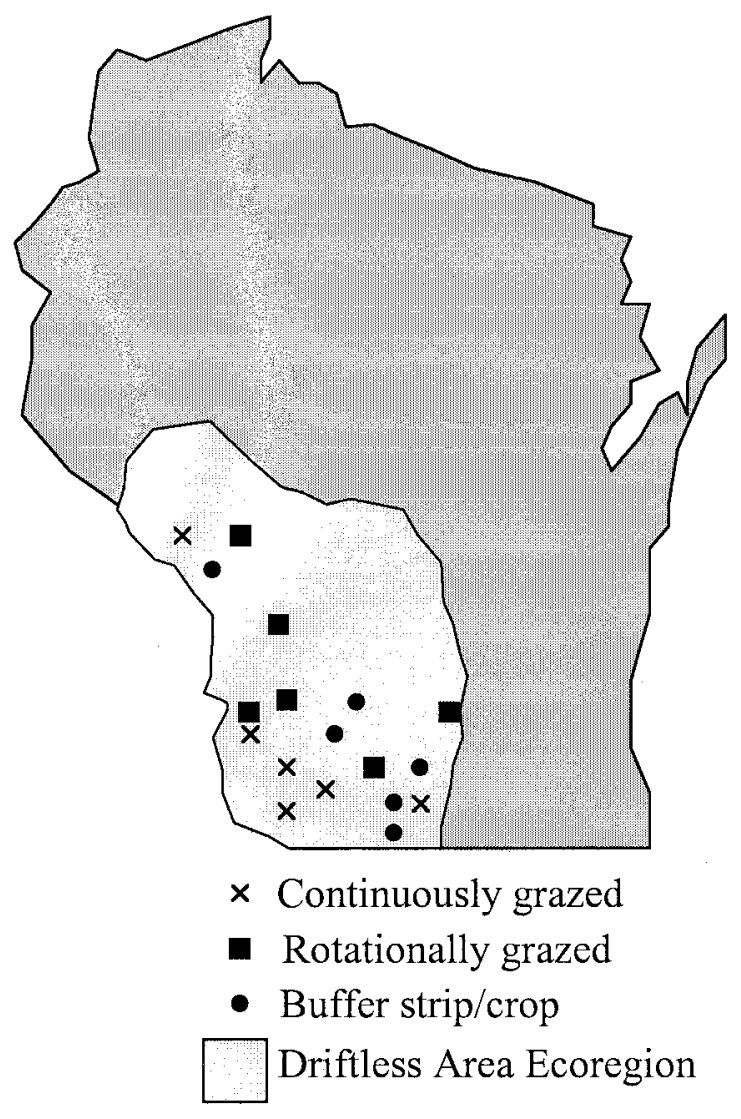

Fig. 1. Location of study sites in southwestern Wisconsin.

riparian pastures and row crops with 10m-wide ungrazed grassy buffer strips along streams (buffer strip/crops). In addition, within the 2 pasture management types, we compared the avian communities near the stream $(<10 \mathrm{~m})$ and away from the stream $(>10 \mathrm{~m})$ to evaluate the within-pasture distribution of birds.

\section{Materials and Methods}

\section{Study area and sites}

Study sites were located along coldwater streams and distributed throughout the Driftless Area in southwestern Wisconsin (Lat. 43 00', Long. 90 22') (Fig. 1). Sites were chosen as part of an interdisciplinary study to assess the impacts of rotational grazing on riparian streams.

Each land use type (continuous grazing, rotational grazing, and buffer strip/crops) was replicated on 4 riparian sites in 1996, but only 2 of the 4 sites from each type were revisited in both 1997 and 1998 because land use changes disqualified some sites each year. These disqualified

\section{Bird surveys}

Birds were surveyed using standard 50m-radius, 5-min point counts (Ralph et al. 1997). Three point count surveys were conducted at each site from mid-May to the end of June, with approximately 2 weeks between each survey. The number of points varied among sites based on site size $($ range $=1-5)$. Points were centered over streams and were separated by at least $150 \mathrm{~m}$ to avoid double counting birds. Points were located so as to fit as many points as possible that contained no trees or fences and were at least $25 \mathrm{~m}$ from pasture and row crop edges when possible. If only 1 point fit into a pasture, it was located as close as possible to the center of the site. In pasture sites, birds located within $10 \mathrm{~m}$ of the stream were recorded separately from all other birds to compare bird communities near $(<10 \mathrm{~m})$ versus away $(>10 \mathrm{~m})$ from streams. The amount of stream area and non-stream area surveyed was calculated for each point circle using distances estimated by pacing the stream length or by calculating areas with a planimeter on aerial photos.

\section{Vegetation structure}

Each year of the study, vegetation data were collected from each study site during the last week in April or the first week in May when breeding birds are establishing territories. Sampling design was a stratified random pattern involving 3 transects perpendicular to the stream on each side of the stream, for a total of 6 transects per site. Three sampling locations along each transect provided a total of 18 observations for each site on each date. Along each transect, 1 sample was collected within $3 \mathrm{~m}$ of the stream. The other 2 samples were collected at randomly chosen stations at least $10 \mathrm{~m}$ away from the stream (upland) along each transect by taking a random number of steps away from the previous location. Data from the 2 upland locations were averaged for analyses. At each sampling location, a 0.5 $\mathrm{m}^{2}$ Daubenmire frame (Daubenmire 1968) was used to obtain estimates of percent bare ground, percent litter cover, percent live vegetation cover, and percent of live cover that was grass, legume or forb. Four random litter depth $(\mathrm{cm})$ measurements were taken within each Daubenmire frame and the results averaged for that sampling location. A Robel pole was used in the center of the frame to obtain vegetation height-density $(\mathrm{cm})$ (visual obstruction measurements) and maximum vegetation height $(\mathrm{cm})$. The procedure used was mod- 
ified from the original Robel method (Robel et al. 1970) by reading the pole from a single height of $1.5 \mathrm{~m}$ rather than from 3 different heights. Readings were taken from the 4 cardinal directions and averaged for each location.

\section{Data Analysis}

Bird species present at a site for 1 or more years were treated as occurring on that site. Species were tabulated by land use type and near/away from the stream. Species were categorized as to their general habitat preferences (i.e., forest, wooded edge, grassland/ cropland, riparian, urban/farmstead, and wetland) (Best et al. 1996). Bird densities (birds $\mathrm{ha}^{-1}$ ) for each site were averaged over the 3 surveys. Bird densities near and away from the stream and densities of only the grassland birds were similarly calculated. Species richness for each site was calculated by counting the number of species seen for all 3 surveys within a year. Species richness near and away from the stream were calculated similarly. Community metrics of species richness, dominance, and overall similarity were calculated for each land use type within each year. The BergerParker Index of Dominance (max [number of individuals of species $i]$ /total number of individuals seen) (Magurran 1988) was calculated for each survey on the site and then averaged for a dominance index for each site. The larger the number, the more numerically dominant a single species was in the community. Dominance indices for near and away from stream were similarly calculated.

Due to changes in some sites from between years, analyses were performed for each year separately. Differences in average site species richness, dominance, density, and average similarity among land use types were tested using generalized linear models (McCullagh and Nelder 1989). Species richness and the Dominance Index were adjusted for effort (Magurran 1988) by including area surveyed as the first term in the models (e.g., when testing for the effect of land use type, the model would be index $=$ overall mean + area surveyed + land use type + error). To evaluate differences between the pasture land use types in the indices between areas near and away from streams, we paired on site (i.e., "near" and "away" were paired) for a split-plot analysis of variance. When an interaction between land use types and near/away status occurred, paired t-tests were used to assess differences in species richness, dominance, or density within each pasture land use type.

Percent bare ground, litter depth, and vegetation height-density were used to assess the importance of vegetation structure in explaining the variation in the bird community metrics. For these analyses, values for each vegetation variable was averaged over the entire site. Species richness and total density for the land use types were modeled with the vegetation variables using backward stepwise generalized linear models (McCullagh and Nelder 1989). Generalized linear models with a Poisson and gaussian error structure were used for species richness and density analyses, respectively. Differences in the community metrics and vegetation for near/away from streams in the pastures were also analyzed using generalized linear models with a gaussian error structure. Individual species distributions within a pasture were not analyzed due to low sample sizes. Trends were assessed at an alpha of 0.10 and significance at 0.05 . All analyses were performed using Splus 4.5 (Mathsoft 1998).

\section{Results}

\section{Bird community comparison among land use types}

Twenty-five bird species were recorded over the 3 years (Table 1); $40 \%$ of these species are considered to be associated with

Table 1. Complete species list for near $(<10 \mathrm{~m})$ and away $(>10 \mathrm{~m})$ from stream in the 3 land use options.

\begin{tabular}{|c|c|c|c|c|c|c|c|}
\hline \multirow[b]{2}{*}{ Species } & \multirow[b]{2}{*}{ Habitat } & \multicolumn{2}{|c|}{ Continuous } & \multicolumn{2}{|c|}{$\begin{array}{l}\text { Treatments } \\
\text { Rotational }\end{array}$} & \multicolumn{2}{|c|}{ Buffer strip/Crop } \\
\hline & & near & away & near & away & near & away \\
\hline Great Blue Heron (Ardea herodius) & $\mathrm{W}^{1}$ & $\mathrm{X}$ & & & & & \\
\hline Wood Duck (Aix sponsa) & W & $\mathrm{X}$ & & & & & \\
\hline Mallard (Anas platyrhynchos) & W & $\mathrm{X}$ & & $\mathrm{X}$ & & $\mathrm{X}$ & \\
\hline Killdeer (Charadrius vociferus) & $\mathrm{G}$ & $\mathrm{X}$ & $\mathrm{X}$ & & $\mathrm{X}$ & & \\
\hline Spotted Sandpiper (Actitis macularia) & W & & & & & $\mathrm{X}$ & \\
\hline Common Snipe (Gallinago gallinago) & W & $\mathrm{X}$ & & & & & \\
\hline Belted Kingfisher (Ceryle alcyon) & $\mathrm{R}$ & $\mathrm{X}$ & $X$ & & & $\mathrm{X}$ & \\
\hline Willow Flycatcher (Empidonax traillii) & $\mathrm{E}$ & & & & & $\mathrm{X}$ & \\
\hline Eastern Phoebe (Sayornis phoebe) & $\mathrm{R}$ & & & $\mathrm{X}$ & $\mathrm{X}$ & & \\
\hline Eastern Kingbird (Tyrannus tyrannus) & $\mathrm{E}$ & & $X$ & $\mathrm{X}$ & $\mathrm{X}$ & & \\
\hline Blue jay (Cyanocitta cristata) & $\mathrm{F}$ & & $X$ & & & & \\
\hline Sedge Wren (Cistothorus platensis) ${ }^{2}$ & $\mathrm{G}$ & $\mathrm{X}$ & $\mathrm{X}$ & & & & \\
\hline Eastern Bluebird (Sialia sialus) & $\mathrm{E}$ & $\mathrm{X}$ & & & $\mathrm{X}$ & & \\
\hline American Robin (Turdus migratorius) & $\mathrm{E}$ & $\mathrm{X}$ & $\mathrm{X}$ & $\mathrm{X}$ & $\mathrm{X}$ & & $\mathrm{X}$ \\
\hline European Starling (Sturnis vulgaris) & $\mathrm{U}$ & & $\mathrm{X}$ & & & & \\
\hline Common Yellowthroat (Geothylypis trichas) & $\mathrm{E}$ & & & & $\mathrm{X}$ & $\mathrm{X}$ & \\
\hline Chipping Sparrow (Spizella passerina) & $\mathrm{E}$ & & $\mathrm{X}$ & & & & \\
\hline Savannah Sparrow (Passerculus sandwichensis) ${ }^{2}$ & $\bar{G}$ & $\mathrm{X}$ & $X$ & $\mathrm{X}$ & $\mathrm{X}$ & $\mathrm{X}$ & \\
\hline Song Sparrow (Melospiza melodia) & $\mathrm{E}$ & $\mathrm{X}$ & $X$ & $X$ & $\mathrm{X}$ & $\mathrm{X}$ & $\mathrm{X}$ \\
\hline Bobolink (Dolichonyx oryzivorus) ${ }^{2}$ & $\mathrm{G}$ & & $X$ & & $\mathrm{X}$ & & \\
\hline Red-wing Blackbird (Agelaius phoeniceus) & $\mathrm{W}$ & $\mathrm{X}$ & $X$ & $\mathrm{X}$ & $X$ & $\mathrm{X}$ & $\mathrm{X}$ \\
\hline Eastern Meadowlark (Sturnella neglecta) ${ }^{2}$ & $\mathrm{G}$ & & $X$ & & $X$ & & \\
\hline Common Grackle (Quiscalus quiscula) & $\mathrm{E}$ & & $X$ & & & & \\
\hline Brown-headed Cowbird (Molothrus ater) & $\mathrm{E}$ & $\mathrm{X}$ & $X$ & $\mathrm{X}$ & $\mathrm{X}$ & & \\
\hline American Goldfinch (Carduelis tristas) & $\mathrm{E}$ & & $\mathrm{X}$ & $\mathrm{X}$ & $\mathrm{X}$ & $\mathrm{X}$ & \\
\hline Total Species & & 13 & 16 & 9 & 12 & 9 & 4 \\
\hline
\end{tabular}

${ }^{1}$ Habitat with which species is associated. $\mathrm{E}=$ Wooded edge (forest edge, shrubland, oldfield); $\mathrm{F}=$ Forest; $\mathrm{G}=\mathrm{Grassland} / \mathrm{Cropland}$; R = Riparian (usually wooded); $\mathrm{U}=\mathrm{Urban} /$ farmștead; W = Wetland (Best et al. 1996).

${ }^{2}$ Grassland bird species of management concern. 
Table 2. Bird community parameters for each year $(n=4)$.

\begin{tabular}{|c|c|c|c|c|c|}
\hline \multirow{2}{*}{$\begin{array}{l}\text { Species } \\
\text { Land Use Type }\end{array}$} & \multirow[b]{2}{*}{ Richness } & \multirow[b]{2}{*}{ Dominance $^{1}$} & \multirow[b]{2}{*}{ Density } & \multicolumn{2}{|c|}{ Species of Management Concern } \\
\hline & & & & Density & Number \\
\hline & $-\left(\right.$ No. site $\left.{ }^{-1}\right)-$ & & $-\left(\right.$ No. ha $\left.^{-1}\right)-$ & $-\left(\right.$ No. ha $\left.{ }^{-1}\right)-$ & \\
\hline \multicolumn{6}{|l|}{1996} \\
\hline Rotational & $4.3 \pm 0.5$ & $0.42 \pm 0.06$ & $1.89 \pm 0.57$ & $1.27 \pm 0.17$ & 2 \\
\hline Buffer strip/crop & $3.3 \pm 0.5$ & $0.34 \pm 0.12$ & $3.52 \pm 0.90$ & $0.21 \pm 0.21$ & 1 \\
\hline \multicolumn{6}{|l|}{1997} \\
\hline Buffer strip/crop & $3.5 \pm 0.5$ & $0.54 \pm 0.05$ & $4.56 \pm 1.06$ & 0 & 0 \\
\hline \multicolumn{6}{|l|}{1998} \\
\hline Continuous & $3.5 \pm 1.2$ & $0.56 \pm 0.17$ & $1.72 \pm 0.56$ & $2.12 \pm 1.14$ & 3 \\
\hline Rotational & $1.8 \pm 0.8$ & $0.84 \pm 0.09$ & $1.73 \pm 1.03$ & $1.24 \pm 0.97$ & 2 \\
\hline Buffer strip/crop & $2.3 \pm 0.6$ & $0.81 \pm 0.08$ & $3.50 \pm 1.25$ & 0 & 0 \\
\hline
\end{tabular}

${ }_{2}$ Berger-Parker Index of Dominance.

${ }^{2}$ Continuously grazed, rotationally grazed, and buffer strip within row crop field.

${ }^{3}$ Mean \pm standard error.

edges, $24 \%$ with wetlands, and $20 \%$ with grasslands. Eighty percent of the grassland species observed were species of management concern. Grassland species were defending territories on the pastures and therefore assumed to be using them for breeding, while all other species were only observed feeding in pastures. Species in buffer strips were defending territories. Species occurring in row crops were only observed feeding, with the exception of Killdeer, which were confirmed to be nesting.

Species richness varied between 1.75 to 5.50 species per site over the 3 years and land use types (Table 2). In any 1 year, species richness per site did not differ among continuous pastures, rotational pastures, and buffer strip/crops $(\mathrm{p}>0.25$, all 3 years). Bird density varied between 1.7 to 4.6 birds ha $^{-1}$ over the 3 years and land use types (Table 2). Within a year, total bird density was not different among land use types ( $p>0.25$, all 3 tests).

Within years, dominance indices were similar between the land use types ( $p>$ 0.05 , all 3 tests). On average, over all years and land use types, dominance was 0.56 (Table 2). On the continuously grazed sites, the dominant species was Savannah Sparrow. On the rotationally grazed sites, the dominant species were Savannah Sparrow and Red-winged Blackbird. On the buffer strip/crop sites, the dominant species was Red-winged Blackbird. Species in common between the buffer strip/crop and continuously grazed sites were Red-winged Blackbird and Song Sparrow, found on the majority of sites in all land use types. However, of the 4 grassland species observed (Table 1) in any 1 year, 3 to 4 of the species were seen on the continuously grazed sites, not on the buffer strip/crop sites. In contrast, bird communities on the continuously grazed and rotationally grazed sites had 2 to 3 of the grassland bird species in common.

Densities of species of management concern as a group (Savannah Sparrow, Eastern Meadowlark, Bobolink, and Sedge Wren) were not significantly different between continuous and rotational pastures within years ( $p>0.4$, all 3 tests). This also was true for Savannah Sparrow, the more commonly occurring species ( $p$ > 0.5 , all tests). Only 2 Savannah Sparrows and none of the other species of management concern were seen on buffer strip/crop sites.

\section{Vegetation-bird community rela- tionships}

Mean values and standard errors for each vegetation parameter measured are presented in Table 3. Species richness was not related to vegetation structure in 2 of the 3 years (i.e., no model was chosen by step-wise selection in 1997 and 1998). In 1996, species richness had a tendency to be related to vegetation height-density $\left(\mathrm{R}^{2}\right.$

Table 3. Vegetation structure measurements for each land use type within each year of the study $(n=4)$.

\begin{tabular}{|c|c|c|c|}
\hline Land Use Type & Bare Ground & Litter Depth & Height-density \\
\hline & -----(\%)----- & -----(cm)----- & -----(cm)----- \\
\hline \multicolumn{4}{|l|}{1996} \\
\hline Continuous $^{1}$ & $11.6 \pm 2.4$ & $1.1 \pm 0.3$ & $9.5 \pm 1.9$ \\
\hline Rotational & $8.7 \pm 3.7$ & $1.5 \pm 0.6$ & $11.6 \pm 3.2$ \\
\hline Buffer strip/crop & $36.8 \pm 1.8$ & $3.5 \pm 0.6$ & $26.2 \pm 1.2$ \\
\hline \multicolumn{4}{|l|}{1997} \\
\hline Continuous & $10.0 \pm 2.3$ & $0.7 \pm 0.1$ & $4.8 \pm 1.3$ \\
\hline Rotational & $6.0 \pm 2.8$ & $1.2 \pm 0.4$ & $13.9 \pm 2.9$ \\
\hline Buffer strip/crop & $36.6 \pm 2.8$ & $3.2 \pm 0.3$ & $24.3 \pm 5.3$ \\
\hline \multicolumn{4}{|l|}{1998} \\
\hline Continuous & $7.8 \pm 1.6$ & $0.7 \pm 0.4$ & $9.6 \pm 2.6$ \\
\hline Rotational & $10.9 \pm 2.3$ & $2.3 \pm 0.8$ & $13.9 \pm 2.2$ \\
\hline Buffer strip/crop & $44.0 \pm 2.1$ & $10.0 \pm 3.8$ & $38.5 \pm 1.7$ \\
\hline
\end{tabular}

$=0.227, \mathrm{P}=0.076)$. In this case, there tended to be higher richness on sites with lower vegetation height-density. These tended to be sites with continuous and rotational grazing compared to the buffer strip/crop sites.

Bird density was related to vegetation structure. In 1996 and 1998, there was a higher density of birds with deeper litter depths (1996: $\mathrm{R}^{2}=0.379, \mathrm{P}=0.033$; 1998: $\left.\mathrm{R}^{2}=0.635, \mathrm{P}=0.002\right)$. Litter was deeper on buffer strip sites compared to the continuous and rotational sites (Table 3). In 1997, there was a tendency for density to be higher with more bare ground (1997: $\left.\mathrm{R}^{2}=0.280, \mathrm{P}=0.077\right)$. Buffer strip/crop sites had more bare ground compared to continuous and rotational sites (Table 3).

Density of grassland species of concern was also related to vegetation structure. In 1996 and 1998, there tended to be a higher density of grassland birds on sites with less bare ground $\left(1996: \mathrm{R}^{2}=0.282, \mathrm{P}=\right.$ $\left.0.075 ; 1998: \mathrm{R}^{2}=0.278, \mathrm{P}=0.078\right)$. There

${ }^{\mathrm{T}}$ Continuously grazed, rotationally grazed, and buffer strip within row crop. 
was less bare ground on continuous and rotational compared to the buffer strip/crops (Table 3). In 1997, there tended to be higher densities of grassland birds on sites with shallower litter depths $\left(\mathrm{R}^{2}=\right.$ $0.291, \mathrm{P}=0.070)$. Litter depth tended to be shallower on the rotational and continuous sites compared to the buffer strip/crop sites (Table 3 ).

\section{Bird community comparison near and away from stream on pastures}

There was some evidence of a difference in species richness near and away from stream on the pastures (Table 4). In 1996, there were fewer species near the stream than away, regardless of pasture type. In 1997, there were differences in species richness near and away from the stream depending on the pasture land use type. Specifically, there were fewer species near the stream than away on continuous pastures; species richness was similar near and away from the stream on rotational pastures. Grassland species were found both near and away from streams, though Bobolink and Eastern Meadowlark were seen only away from the streams (Table 1).

There was no consistent difference in total bird density near and away from stream on the pastures (Table 4). In 1996, there tended to be more birds near the stream than away, regardless of pasture type. In 1998, there were differences in densities near and away from the stream, depending on pasture type. Specifically, on continuously grazed pastures, there were more birds near the stream than away; there was no difference in densities near and away from streams on rotationally grazed pastures.

This pattern differed for grassland species of concern (Table 4). In 1997 and 1998, there tended to be higher densities of grassland species of concern away from the stream, regardless of pasture type.

Differences in species richness between near and away from streams were not related to differences in vegetation structure ( $\mathrm{p}>0.25$, all models). There were some differences in bird density related to vegetation structure near and away from streams, but these were not consistent among years. No density differences were related to vegetation structure differences in 1996. In 1997, density differences were related to litter depth differences $\left(\mathrm{R}^{2}=\right.$ $0.632, P=0.02)$. Specifically, there were higher densities of birds near the stream when near-stream litter was shallower than away from stream. In 1998, besides being associated with pasture type, density dif-

Table 4. Comparison of bird communities near $(<10 \mathrm{~m})$ and away $(>10 \mathrm{~m})$ from stream in continuous and rotational pasture sites $(n=4$ for each pasture type in each year).

\begin{tabular}{|c|c|c|c|c|}
\hline \multicolumn{2}{|c|}{ Land Use Type } & \multirow{2}{*}{$\frac{\text { Species richness }}{----\left(\text { No. } \text { site }^{-1}\right)----}$} & Total Density & \multirow{2}{*}{$\frac{\text { Density of species of concern }}{----\left(\text { Birds ha }^{-1}\right)----}$} \\
\hline & & & ----(Birds ha $\left.{ }^{-1}\right)----$ & \\
\hline \multirow[t]{3}{*}{1996} & Continuous $^{1}$ & -- & -- & -- \\
\hline & Rotational & -- & -- & -- \\
\hline & $\begin{array}{l}\text { Both pasture } \\
\text { types }\end{array}$ & $\begin{array}{c}\text { near }<\text { away } \\
\mathrm{t}=-2.9, \mathrm{df}=7, \mathrm{P}=0.022\end{array}$ & $\begin{array}{c}\text { near }>\text { away } \\
\mathrm{t}=2.26, \mathrm{df}=7, \mathrm{P}=0.06\end{array}$ & $\begin{array}{c}\text { near } \pm \text { away } \\
\mathrm{t}=0.79, \mathrm{df}=7, \mathrm{P}=0.45\end{array}$ \\
\hline \multirow[t]{5}{*}{1997} & Continuous & near $<$ away & & \\
\hline & & $2.5 \pm 0.9<4 \pm 0.9$ & -- & -- \\
\hline & Rotational & near \pm away-- & -- & \\
\hline & Both pasture & Interaction & near \pm away & near $<$ away \\
\hline & types & $\mathrm{F}=8, \mathrm{df}=1,6, \mathrm{P}=0.03$ & $P>0.25$, all tests & $\begin{array}{c}0.9 \pm 0.5<6.0 \pm 2.3 \\
t=-2.15, d f=7, P=0.69\end{array}$ \\
\hline \multirow[t]{4}{*}{1998} & Continuous & -- & near > away & -- \\
\hline & & -- & $3.8 \pm 1.2>1.4 \pm 0.7$ & -- \\
\hline & Rotational & -- & near \pm away & -- \\
\hline & $\begin{array}{l}\text { Both pasture } \\
\text { types }\end{array}$ & $\begin{array}{c}\text { near } \pm \text { away } \\
P>0.25 \text {, all tests }\end{array}$ & $\begin{array}{c}\text { Interaction } \\
\mathrm{F}=8.75, \mathrm{df}=1,6, \mathrm{P}=0.002\end{array}$ & $\begin{array}{c}\text { near }<\text { away } \\
0.6 \pm 0.4<2.3 \pm 1.0 \\
\mathrm{t}=-1.98, \mathrm{df}=7, \mathrm{P}=0.088\end{array}$ \\
\hline
\end{tabular}

${ }^{\mathrm{C}}$ Continuously grazed, rotationally grazed, and buffer strip within row crop.

ferences were associated with vegetation height-density differences $\left(\mathrm{R}^{2}=0.91, \mathrm{P}=\right.$ $0.01)$. Specifically, there were higher densities of birds near the stream when vegetation height-density was higher near the stream compared to away from stream.

For grassland species of concern in 1996, density differences tended to be associated with differences in vegetation height-density $\left(\mathrm{R}^{2}=0.409, \mathrm{P}=0.088\right)$. Specifically there tended to be more grassland birds near the stream when vegetation height-density was higher near the stream compared to away from streams. No vegetation parameters were associated with grassland bird density differences in 1997. In 1998, differences in bare ground and litter depth were associated with differences in grassland bird densities $\left(\mathrm{R}^{2}=\right.$ $0.706, P=0.03$ for bare ground; $P=0.053$ for litter depth). In this case, densities of grassland birds were higher near the stream when there was more bare ground or when litter depth was shallower.

\section{Discussion and Conclusions}

Species richness, dominance, and density were similar between the 3 land use types. Continuous and rotational pastures supported grassland bird species of management concern: Savannah Sparrow, Eastern Meadowlark, and Bobolink. Sedge Wrens were also found on continuous pastures. With the exception of 2 Savannah Sparrows observed during 1 survey, species of management concern did not occur on the $10-\mathrm{m}$ buffer strips. This is similar to the results of Holmquist (1991), who rarely found Eastern Meadowlarks on ungrazed herbaceous riparian buffer strips located within grazed pastures in Pennsylvania, and found no Savannah Sparrows or Bobolinks despite their presence in the general study area. In contrast, ungrazed grassed waterways of greater width have been shown to support breeding grassland birds such as Savannah Sparrow, Eastern Meadowlark, Bobolink, and Sedge Wren (Robert Howe, Wisconsin Dep. Nat. Resources, 1999, unpubl. report), as well as Western Meadowlark, Dickcissel (Spiza americana Gmelin), and Grasshopper Sparrow (Bryan and Best 1991). Unlike the riparian buffer strips in this study, however, grassed waterways are non-riparian grassy strips located in upland crop fields, rather than in lowland areas along streams, which may account for the differences between this study and those conducted in grassed waterways. Linear grassland habitats, such as road rights-of-way, of similar width to the buffer strips and also surrounded by crop fields, can support species of management concern such as Eastern and Western Meadowlarks, Sedge Wren, Dickcissel, and Savannah Sparrow (Warner 1992, Camp and Best 1993). Buffer strips in this study may have been unsuitable for species of management concern because of their extremely dense, tall vegetation, steep streamside slopes, potential for flooding, limited width, location within unsuitable row crops, the presence of scattered shrubs, or a combination of these factors.

Overall bird density was related to vegetation structure, with higher densities located on sites with deeper litter. This result was partially driven by the buffer 
strips, which had higher bird densities and greater litter depth than the pastures. It is interesting to note that litter depths were high enough in buffers to more than compensate for the abundance of litter depth values of 0 found in adjacent row crops, yielding overall higher litter depth values than in pastures. Positive correlations between bird density and litter depth have been found in previous studies of similar bird communities (Sample 1989, Wiens and Rotenberry 1981).

Density of species of management concern tended to be negatively correlated with bare ground. This result was driven by buffer strip/crop sites, which had very high proportions of bare ground in the cropland and few species of management concern. Grassland bird densities have been found to be negatively correlated with bare ground in other studies (Sample 1989, Wiens 1974).

Within the pastures in our study, there was no consistent influence of proximity to streams on overall species richness, density, or dominance. There was a trend for grassland birds of management concern to differ in occurrence and density near and away from streams in pastures. These species tended to occur more frequently and at higher densities away from the stream, regardless of pasture management. These results differ from studies conducted in forest and shrub species in western (Anderson et al. 1994, Knopf 1985), southwestern (Medin and Clary 1991, Stahlecker et al. 1989, Szaro 1981), and Great Plains (Lowther 1984, Stauffer and Best 1980, Tubbs 1980) riparian areas, which found higher bird species richness and/or density in riparian areas than in other habitats in general. In contrast to the previous studies, the vegetation structure adjacent to the pasture streams in our study does not differ dramatically from the structure in the rest of the pasture.

Densities of all species as well as species of management concern showed the same patterns in relation to vegetation near and far from streams in pastures. Specifically, densities tended to be higher near streams when the litter depth was lower and vegetation height-density was higher than away from streams. These results differ from most other studies on grassland birds in non-riparian habitats. In 1 Wisconsin farmland study (Sample 1989), grassland bird density was positively correlated with moderate litter and negatively correlated with vegetation heightdensity and low litter. Wiens (1974) evaluated grassland bird-vegetation relationships on a continental scale and found a tendency for greater bird densities to be associated with areas with greater litter depth and grass cover and less bare ground. Rotenberry and Wiens (1980) found the same relationships for eastern tallgrass species (Grasshopper Sparrow, Dickcissel, and Eastern Meadowlark). Comparisons with other studies are difficult, however, since correlations reflect the habitat chosen relative to habitat availability in the study area.

We found that pastures, regardless of type of management, supported higher average densities of grassland species of concern than buffer strip/crops. We also found no difference in grassland bird density between continuously and rotationally grazed pastures. This finding differs from the results of a previous study in the same region of Wisconsin (Temple et al. 1999). In their study, the same grassland species of concern (Sedge Wren, Savannah Sparrow, Eastern Meadowlark, and Bobolink) were more abundant on rotationally grazed pastures than continuously grazed pastures. This discrepancy may be due to differences in the types of sites evaluated. Although both studies were conducted within the Driftless Area of southwestern Wisconsin, this study evaluated riparian lowland pastures, whereas the study conducted by Temple et al. (1999) evaluated upland pastures. There is evidence that some grassland species of management concern occur more frequently and/or at higher density in upland pastures than in lowland pastures (Renfrew 1999).

Another possible explanation for the discrepancy is that the vegetation structure in continuous pastures appears to have been different between this study and that of Temple et al. (1999). Continuous pastures in Temple et al. (1999) had "little vegetative cover and were kept closely cropped by cattle". In contrast, some of the continuous pastures in this study were not heavily grazed and supported Sedge Wrens, a species known to avoid short grass. Heavy grazing that maintains low vegetative cover and height-density is generally less favorable to grassland birds of management concern than light or moderate grazing (see Bock et al. 1992, Herkert et al. 1996, and Swanson 1996 for a review). The continuous pastures in this study likely represented more moderate stocking rates than Temple et al. (1999), which may explain our different conclusions. The stocking rates selected for a study may heavily influence results when comparing continuous grazing to other grazing treatments or land uses.
It is clear that pastures provided better habitat for grassland bird species of management concern than 10-m-wide buffer strip/crops. Therefore, if management is focused on these species, pastures should be favored over 10-m-wide ungrazed buffer strips along streams located within row crop fields. Research has not yet been conducted to determine how wide buffer strips should be to benefit grassland birds (D. Sample, Wisconsin Department of Natural Resources, pers. comm.). Because grassland bird species of management concern tend to occur at lower densities adjacent to streams, management decisions that affect land use at the scale of the farm are likely to have a much greater impact on these species than stream management decisions affecting only the immediate riparian area.

\section{Literature Cited}

Anderson, B.W., R.D. Ohmart, and H.A. Allen, Jr. 1994. Riparian birds in the riparian/ agricultural interface, p. 190-195 In: Warner, R.E. and K.M. Hendrix (eds.), California riparian systems. Univ. California Press, Berkeley, Calif.

Best, L.B., K.E. Freemark, J.J. Dinsmore, and M. Camp. 1996. A review and synthesis of habitat use by breeding birds in agricultural landscapes of Iowa. Amer. Midl. Nat. 134:1-29.

Bryan, G.G. and L.B. Best. 1991. Bird abundance and species richness in grassed waterways in Iowa rowcrop fields. Amer. Midl. Nat. 126:90-102.

Bock, C.E., V.A. Saab, T.D. Rich, and D.S. Dobkin. 1992. Effect of livestock grazing on Neotropical migratory landbirds in western North America, p. 296-309. In: National Training Workshop, Status and Management of Neotropical Migratory Birds, Executive Summaries. U.S. Forest Service General Technical Report RM-229. Washington, D.C. Camp. M. and L.B. Best. 1993. Bird abundance and species richness in roadsides adjacent to Iowa rowcrop fields. Wildl. Soc. Bull. 21:315-325.

Daubenmire, R. 1968. Plant communities: a textbook of plant synecology. Harper and Rowe Publishers, New York, N.Y.

Herkert, J.R. 1991. Prairie birds of Illinois: population response to two centuries of habitat change. Ill. Nat. History Surv. Bull. 34:393-399.

Herkert, J.R., Sample, D.W., and R.E. Warner. 1996. Management of midwestern grassland landscapes for the conservation of migratory birds, p. 89-116. In: Thompson, F.R. (ed.), Management of midwestern landscapes for the conservation of neotropical migratory birds. USDA For. Serv. Gen. Tech. Report NC-187. Washington, D.C. 
Holmquist, C.L. 1991. Avian use of riparian corridors located in grazed pastures. MS Thesis, Pennsylvania State Univ., University Park, Penn.

Jones, A.L. and P.D. Vickery. 1996. Conserving grassland birds. Center for Biol. Conserv., Massachusetts Audubon Society, Lincoln, Mass.

Knopf, F.L. 1985. Significance of riparian vegetation to breeding birds across and altitudinal cline, p.105-111. In: Riparian ecosystems and their management: reconciling conflicting uses. USDA For. Serv. Gen. Tech. Rep. RM-120. Washington, D.C.

Knopf, F.L. 1995. Declining grassland birds, p. 296-298. In: LaRoe, E.T., G.S. Farris, C.E. Puckett, P.D. Doran, and M.J. Mac (eds.), Our Living Resources. US Dept. of InteriorNat. Biol. Serv. Washington, D.C.

Lowther, P.E. 1984. Repeat of a 1916 bird census in northwestern Iowa (USA). Proc. Iowa Acad. Sci. 91:87-91.

Magurran, A.E. 1988. Ecological diversity and its measurement. Princeton Univ. Press, Princeton, N.J.

Mathsoft, Inc. 1998. Splus Version 4.5. Seattle, Wash.

McCullagh, P. and J.A. Nelder. 1989. Generalized linear models. Chapman and Hall, New York, N.Y

Medin, D.E. and W.P. Clary. 1991. Breeding bird populations in a grazed and ungrazed riparian habitat in Nevada, pp.1-7. In USDA For. Serv. Gen. Tech. Rep., INT-441. Washington, D.C.
Ralph, C.J., J.R. Sauer, and S. Droege. 1997. Monitoring bird populations by point counts. USDA For. Serv. Gen. Tech. Rep. PSW-149. Washington, D.C.

Renfrew, R.B. 1999. The influence of agricultural land use and physiography on grassland birds in the Wisconsin Driftless area. M.S. thesis, Univ. Wisconsin, Madison, Wisc.

Robel, R.J., J.N. Briggs, A.D. Dayton, and L.C. Hulbert. 1970. Relationships between visual obstruction measurements and weight of grassland vegetation. J. Range Manage. 23:295-297.

Rotenberry, J.T. and J.A. Wiens. 1980. Habitat structure, patchiness, and avian communities in North American steppe vegetation: a multivariate analysis. Ecol. 61:1228-1250.

Sample, D. 1989. Grassland birds in southern Wisconsin: habitat preference, population trends, and response to land use changes. M.S. Thesis, Univ. Wisconsin, Madison, Wisc.

Sample, D.W. and M.J. Mossman. 1997. Managing habitat for grassland birds: a guide for Wisconsin. Wisconsin Dept. Nat. Resources, Madison, Wisc.

Stahlecker, D.W., P.L. Kennedy, A.C. Cully, and C.B. Kuykendall. 1989. Breeding bird assemblages in the Rio Grande Wild and Scenic River Recreation Area, New Mexico (USA). Southwestern Nat. 24:487-498.

Stauffer, D.F. and L.B. Best. 1980. Habitat selection by birds of riparian communities: evaluating effects if habitat alterations. J. Wildl. Manage. 44:1-15.
Swanson, D.A. 1996. Nesting ecology and nesting habitat requirements of Ohio's grassland-nesting birds: a literature review. Ohio Fish and Wildl. Rep. 13. Div. of Wildl., Ohio Dept. Nat. Resources.

Szaro, R.C. 1981. Bird population responses to converting chaparral to grassland and riparian habitats. Southwestern Nat. 26:251-256.

Temple, S.A., B.M. Fevold, L.K. Paine, D.J. Undersander, and D.W. Sample. 1999. Nesting birds and grazing cattle: accommodating both on Midwestern pastures. Studies Avian Biol. 19:196-202.

Tubbs, A.A. 1980. Riparian bird communities of the Great Plains, p. 419-433. In: USDA For. Serv. Gen. Tech. Report INT-86. Washington, D.C.

Warner, R.E. 1992. Nest ecology of grassland passerines on road rights-of-way in central Illinois. Biol. Cons. 59:1-7.

Wiens, J.A. 1974. Habitat heterogeneity and avian community structure in North American grasslands. Amer. Midl. Nat. 91:195-213.

Wiens, J.A. and J. T. Rotenberry. 1981. Habitat associations and community structure of birds in shrub-steppe environments. Ecol. Monographs 51:21-41.

Wisconsin Natural Heritage Program. 1999. Wisconsin Natural Heritage Working List. Wisconsin Bureau of Endangered Resources, Madison, Wisc. 